\title{
New York Tree Fruit Breeders
}

\author{
Susan K. Brown \\ Department of Horticultural Sciences, Cornell University, New York State Agricultural Experiment Station, Geneva, NY 14456
}

The quote "I have drunk from wells I have not dug and been warmed by fires that I did not build" with unknown attribution describes our dependence on breeders before us. While there have been many remarkable tree fruit breeders in New York, including Ulysses P. Hedrick (1870-1951), I will only cover Robert Lamb and Roger Way, whom I have known personally.

\section{ROBERT CORNWALL LAMB}

People magazine featured apple breeders Bob Lamb and Roger Way in an article and said that, for them, "pomology is a magnificent obsession." Bob has also been featured in newspaper articles "Apple Polisher" and "In Pursuit of the Perfect Apple."

BobLamb was born in Saskatoon, Saskatchewan, Canada(1919-1997). He obtained his MS and $\mathrm{PhD}$ degrees at the University of Minnesota. He started at Cornell University's New York StateAgriculturalExperiment Station in Geneva in 1949 as an assistant professor.

He chose research projects that were very challenging, including resistance to pear psylla, the early introgression of apple scab resistance genes, breeding apples with multiple resistances (scab, mildew, cedar apple rust, and fire blight), cold hardiness of stone fruit, and the inheritance of bitter versus sweet kernels in apricots. As new techniques became available, Bob was eager to collaborate, as exemplified by his research with Norman Weeden on genetics and linkage analysis in apple using isozymes. Bob's resistance research, in collaboration with Herb Aldwinckle, added greatly to our knowledge of resistance mechanisms and provided valuable germplasm for future breeding

Bob was responsible for the development and naming of the following cultivars: the scab-resistant 'Liberty' (1978) and 'Freedom' (1983) apples, 'New Yorker' (1967) nectarine, 'Brighton' (1972) and 'Eden' (1972) peaches, and 'Aurora' (1964) and 'Highland' (1974) pears.

Bob was active in the American Pomological Society (serving as its president for two terms), the Apple and Pear Breeders' Cooperatives, and the American Society for Horticultural Science. He was awarded the Wilder medal from the American Pomological Society in recognition of his research in fruit breeding. He was active in the New York Fruit Testing Association, and his activities were instrumental in the development of the U.S. Department of Agriculture's National Clonal Repository for Apples and Grapes at Geneva.

Bob typified the hard-working, dedicated scientist who continued to come in every day even after he had to bring along a tank of supplemental oxygen. Once, a group of us had planned a canoe trip over a long weekend and Bob expressed concern because "we don't get Columbus day off." A colleague said, "Bob, you are retired-you get every day off!
Bob also had a great sense of humor. He pretended to take great offense at a description of him wearing a "flannel shirt and gray sweater of unknown provenance."You could often hear his deep laugh echoing down the hallways, or catch the gleam in his eye as he listened to stories from his colleagues. He loved to tell of the box that arrived in his office with the letter asking "Could you help identify this apple, I apologize but it was so good we ate it, but enclosed are the core and seeds."

Bob was a genuinely warm, enthusiastic, and positive individual who served as a mentor to students and colleagues. Bob was also someone who had a life beyond his career. He was active in the community, boy scouts, and the church. He was a member of a bridge group and was always looking to recruit some new members. He was a member of the yacht club, with his yacht a canoe. Bob was dedicated to his family: his wife Barbara, his children David (Michéle), Betsy, Bill(Lauren), and his grandchildren Christopher, Robert, and Alison. Bob was very pleased that his daughter Betsy, now a state specialist in extension at the University of Florida, followed in his footsteps, but he was equally proud of all his children. Bob was a natural with children, as evidenced by his ability to connect with them during school field trips to the orchard.

Bob described fruit breeding as analogous to the explorers in the past who were visiting a new land for the first time. He said that "when you are evaluating seedlings you are experiencing this new combination of traits for the first time, no one else has tasted this, and right before you bite you are thinking: Is this the one?" May we all hold that view, enthusiasm, and spirit.

\section{ROGER DARLINGTON WAY}

Roger Way was born in 1918 and was raised on a fruit and dairy farm, attended a one-room schoolhouse, was a member of the Religious Society of Friends (Quakers), and was active in postwar relief work in Honan and Yunnan, China, where he learned Chinese. Roger received his $\mathrm{PhD}$ at Cornell in 1953 with his advisor Louis Edgerton and Henry Munger, Dan Clark, and A.J. Heinicke committee members. He started his career at Cornell University's New York State Agricultural Experiment Station as an assistant professor in the same year.

Roger was, first and foremost, involved in breeding apple, but also bred cherries and elderberries, examined the use of crabapples as pollenizers, and studied fruit-tree nursery propagation techniques and machine pruning of apple orchards. He is best known for his 1966 release of 'Empire' (with J. Einset and L. Klein) and 'Jonagold' (with R. LaBelle and J. Einset) apples. Both of these cultivars were recipients of the Outstanding Fruit Cultivar Award from the Fruit Breeding Working group of the American Society for Horticultural Science. Roger was hosted in Japan in honor of his creation of 'Jonagold', a wonderful recognition of his research and its impact. Roger also introduced 'Spijon' (1968), 'Jonamac'(1972), 'Burgundy' (1974), 'Early Cortland'(1982), 'Geneva Early' (1982), 'Empress'(1988), and 'Northern Lights' (1990) apples; 'Ulster'(1964), 'Hudson'(1964), and 'Kristin' (1982) sweet cherries; and 'York' (1964) elderberry.

Roger was awarded the Wilder Medal from the American Pomological Society in 1982, the Golden Apple Award from the New York Apple Industry in 1985, the Milo Gibson award from the North American Fruit Explorers in 1986. In 1987, Pennsylvania State University Alumni named him an alumni fellow.

Roger has a serious demeanor and has always dressed very professionally for field days and professional meetings. He is the only one I know who has work boots that gleam with polish. $\mathrm{He}$ is a natural at giving presentations and has attracted a lot of media attention in his role as apple breeder. However, his seriousness seemed to incite reporters to add teasing comments in their articles such as "Roger Way is Looking for a Perfect 10" (an Apple that is)" and "A Couple of Hundred Apples a Day keep Dr. Roger Way Good to the Core.".

Roger was a wonderful to me when I was hired to take responsibility for his program and the disease resistance-breeding program of Bob Lamb. He was generous with information and referred questions to me as the new breeder, even though growers may have preferred at the time to speak with Roger. He never second-guessed my decisions. He gave me many of his books and even transferred his extensive collection of publications from the American Society for Horticultural Science to my office for the grand sum of $\$ 1.00$ and wrote me a receipt! I am very grateful for how he handled the transition between his program and mine.

Many progeny were the rule in Roger's breeding, with vast seedling orchards filling station acreage. Roger researched the pale-green lethal gene in apple, addressed ways to reduce the juvenile period, studied virus transmission in cherries and was interested in pollination research. His publications also included pollen incompatibility groups in cherry and Malus germplasm He wrote many extension publications on apple varieties for reference by researchers and growers.

Roger is a very private individual, but at times you would hear him talk of his children Edward, Charles, Thomas, and Shirley. He also would return from a visit to relatives in Florida with a few good-natured rumblings about the state. Roger and his wife Mary have retired to Pennsylvania, where Roger can still be found attending the weekly seminar series and, undoubtedly, asking questions of the speaker. He is a testament to the health properties of apples. His legacy is found in his publications and in the popularity of 'Empire' and 'Jonagold' in New York, the U.S. and internationally. 